\title{
Trening węchowy (rehabilitacja zmysłu węchu) u chorych po przebytym COVID-19
}

\section{Olfactory training (rehabilitation of the sense of smell) in patients after COVID-19}

\author{
Piotr Rapiejko \\ Klinika Otolaryngologii i Onkologii Laryngologicznej \\ z Klinicznym Oddziałem Chirurgii Czaszkowo-Szczękowo-Twarzowej, \\ Wojskowy Instytut Medyczny w Warszawie
}

\section{Streszczenie:}

Utrata węchu to częsty objaw towarzyszący zachorowaniu na COVID-19. Powrót prawidłowej funkcji węchu jest zwykle obserwowany w ciągu kilku tygodni od wyzdrowienia. Jednak u ok. 10\% chorych dochodzi do trwałego lub przewlekłego zaburzenia zmysłu węchu, takiego jak osłabienie węchu (hiposmia) lub utrata węchu (anosmia). W pierwszym okresie terapii zaburzeń węchu, podobnie jak w przypadku zapalenia zatok przynosowych, są stosowane donosowe glikokortykosteroidy. Jeśli utrata węchu trwa dłużej niż 2 tygodnie, poza leczeniem farmakologicznym jest zalecany trening węchowy. Duża plastyczność neuronalna zmysłu węchu stwarza możliwości terapii za pomocą stymulacji zmysłu węchu poprzez codzienną ekspozycję na określone zapachy.

\begin{abstract}
:
Loss of smell is a common symptom reported by patients with COVID-19 disease. Return of normal olfactory function is usually observed within a few weeks of recovery. However, about $10 \%$ of patients develop permanent or chronic olfactory impairment, such as olfactory weakness (hyposmia) or olfactory loss (anosmia). Intranasal glucocorticosteroids are used in the initial treatment of olfactory disorders, similar to sinusitis. If the loss of smell lasts longer than 2 weeks, olfactory training is recommended in addition to drug treatment. The high neuronal plasticity of the sense of smell provides opportunities for treatment by stimulating the sense of smell through daily exposure to specific odors.
\end{abstract}

Słowa kluczowe: utrata węchu, zmysł węchu, leczenie, trening węchowy Key words: loss of smell, olfactory function, treatment, olfactory training

\section{Wstęp}

W przebiegu infekcji wirusem SARS-CoV-2 $\mathrm{u}$ wielu pacjentów występują zaburzenia lub utrata zmysłu węchu i smaku. Ewolucja kliniczna utraty węchu obserwowanej w przebiegu COVID-19 nadal pozostaje niejasna. Doniesienia o powrocie prawidłowej funkcji zmysłu węchu różnią się znacznie, od $4 \%$ do $89 \%$ po miesiącu od wystąpienia anosmii $[1,2]$. Badania $\mathrm{z}$ wykorzystaniem testów psychofizycznych wykazały utrzymywanie się zaburzeń węchu u $37-52 \%$ chorych przez 5 tygodni po wystąpieniu anosmii $[2,3]$. Z zaburzeniami zmysłu węchu spotykaliśmy się w codziennej praktyce lekarskiej już wcześniej, w przebiegu przeziębień i grypy. Utrata węchu spowodowana przez COVID-19 może być bardziej powszechna i bardziej nasilona niż w innych wirusowych infekcjach górnych dróg oddechowych. Utrata węchu może u wielu pacjentów nasilić choroby współistniejące, takie jak depresja czy zaburzenia funkcji poznawczych [4]. U licznych chorych z utratą węchu 
jest obserwowane również niedożywienie. Obecnie (lipiec 2021 r.) nadal nie ma opartej na dowodach naukowych interwencji medycznej, która byłaby skuteczna w anosmii spowodowanej przez COVID-19. W niektórych badania wykazano, że systemowe i miejscowe glikokortykosteroidy poprawiają węch u części pacjentów z powirusowym uszkodzeniem zmysłu węchu (PVOD, post-viral olfactory dysfunction) $[5,6]$. W przypadku przedłużających się dolegliwości związanych z utratą lub zaburzeniami węchu jest zalecany trening węchowy [7].

\section{Znaczenie zmysłu węchu}

Znaczenie narządu węchu [8]:

- ostrzeganie o niebezpiecznych substancjach w otoczeniu, zagrażających życiu i zdrowiu (dym, gazy trujące)

- lokalizacja źródła niebezpiecznego lub nieprzyjemnego zapachu

- dobór właściwych pokarmów (ich jakość i świeżość)

- utrzymywanie na odpowiednim poziomie fizjologicznego łaknienia

- udział w procesie wydzielania śliny i soku żołądkowego pod wpływem przyjemnych zapachów żywności

- ważny udział w percepcji wrażeń smakowych

- tworzenie uczucia pełnego komfortu psychicznego

- wpływ na jakość życia dzięki odczuwaniu i ocenie zapachów otaczającej przyrody

- źródło przeżyć i odczuć estetycznych, zachowań emocjonalnych i seksualnych

- samokontrola stanu higienicznego (zapach wydalin, potu)

- droga docierania do istotnych informacji społecznych (rozpoznanie matki, dziecka, odruch ssania).

\section{Przyczyny upośledzenia zmysłu węchu}

Prawidłowe funkcjonowanie zmysłu węchu nazywamy normosmią.

Najczęstsze zaburzenia węchu to: anosmia brak wrażeń węchowych; hyposmia - upośledzenie węchu; parosmia, kakosmia - odczuwanie odmiennych, nienormalnych doznań węchowych (halucynacje węchowe); hiperosmia - nadwrażliwość węchowa.

Przyczyną upośledzenia lub braku węchu mogą być zarówno zaburzenia typu przewodzenia bodźca, jak i zaburzenia neuronu węchowego [9].

Najczęstszą przyczyną zaburzeń typu przewodzenia jest niedrożność jam nosa w przebiegu: polipów nosa (przewlekłe zapalenie zatok przynosowych z polipami nosa), skrzywienia przegrody nosa, przerostu małżowin nosowych, zapalenia alergicznego błony śluzowej nosa, zapalenia zatok przynosowych z zajęciem części węchowej błony śluzowej nosa, zmian w obrębie błony śluzowej jam nosa (np. zaburzenia wydzielania lub składu śluzu), wad rozwojowych i zmian pourazowych, guzów nosa i nosogardła. Najczęstszą przyczyną upośledzenia węchu jest utrudnienie kontaktu substancji zapachowych zawartych $\mathrm{W}$ powietrzu z zakończeniami nerwów węchowych spowodowane niedrożnością nosa w obrębie przewodu nosowego środkowego i górnego, patologiczną, gęstą lub zaschniętą wydzieliną pokrywającą nabłonek węchowy i uniemożliwiającą kontakt substancji zapachowych z powietrza z nabłonkiem węchowym, zaburzeniami składu śluzu lub uszkodzeniem błony śluzowej nosa w okolicy węchowej.

Przyczyny zaburzeń węchu leżące po stronie neuronu węchowego to przede wszystkim [9]: urazy czaszki, szczególnie ze złamaniem podstawy przedniego dołu czaszki (przerwanie nitek węchowych, stłuczenie opuszki), uszkodzenie opuszki w mechanizmie przeciwuderzenia (np. upadek na tyłogłowie), ostre zakażenia wirusowe, zmiany zapalne (zapalenie opon mózgowych, kiła), krwotok podpajęczynówkowy, guzy przedniego dołu czaszki (oponiak rynienki nerwowej, glejak opuszki, glejak płata czołowego, tętniak), urazy jatrogenne, przewlekły zanikowy nieżyt nosa, ekspozycja na związki toksyczne, pyły nieorganiczne, dym tytoniowy, zaburzenia hormonalne, cukrzyca, nałogowe zażywanie kokainy, przyjmowanie leków o działaniu toksycznym na nerwy węchowe (np. aminoglikozydów), choroba Alzheimera, choroba Parkinsona, zaburzenia związane $\mathrm{z}$ wiekiem podeszłym (presbyosmia).

W przebiegu infekcji wirusowej górnych dróg oddechowych u ok. $60 \%$ chorych dochodzi do pogorszenia/utraty węchu. Najczęstsze mechanizmy to stan zapalny błony śluzowej nosa z towarzyszącym obrzękiem błony śluzowej i uszkodzenie nabłonka węchowego, rzadziej mechanizm neurogenny.

W przebiegu COVID-19 zaburzenia zmysłu węchu są w mniejszym stopniu spowodowane obrzękiem błony śluzowej nosa i stanem zapalnym. Różnica między utratą węchu w przebiegu zakażenia SARS-CoV-2 i zwykłej infekcji górnych dróg oddechowych polega na braku współwystępowania przekrwienia błony śluzowej nosa w przypadku zakażenia SARS-CoV-2. Białko ACE2, dzięki któremu SARS-CoV-2 łączy się z komórkami, występuje w dużych ilościach na komórkach nabłonkowych 
błony śluzowej jamy ustnej i nosogardła. Może to thumaczyć mechanizm patofizjologiczny leżący u podłoża zaburzeń zmysłu smaku i węchu u pacjentów zakażonych SARS-CoV-2 [10].

Prawdopodobny mechanizm uszkodzenia zmysłu węchu w przebiegu infekcji SARS-CoV-2 jest związany z dwiema drogami infekcji układu nerwowego [11]:

- drogą krwiopochodną - poprzez ekspresję ACE2 w śródbłonku naczyń kapilarnych (bariera krewmózg) oraz poprzez infekcje monocytów i makrofagów, które mogą pokonać barierę krew-mózg

- drogą neurogenną - wstecznie poprzez zakończenia nerwowe w tkankach i transport wzdłuż aksonu (poprzez nerwy węchowe, nerw błędny, nerw trójdzielny) [11].

\section{Leczenie zaburzeń węchu}

Wyjątkowa sytuacja, w jakiej się znaleźliśmy w 2020 r., spowodowała, że wiele czasopism publikowało doniesienia dotyczące COVID-19 w wersjach elektronicznych, w ekspresowym tempie, zaznaczając jednocześnie na swoich stronach internetowych, że liczne prace nie przeszły należytej ścieżki recenzji. W pierwszych miesiącach pandemii (w 2020 r.) opublikowano wiele sprzecznych doniesień na temat stosowania donosowych glikokortykosteroidów (dnGKS). Dla przykładu francuska agencja rządowa ds. zdrowia (DGS, Direction Générale de la Santé) nie zalecała (stan na kwiecień 2020 r.) przyjmowania dnGKS w anosmii bez towarzyszącej niedrożności nosa [12]. Rozszerzyła ona przeciwwskazania do płukania jam nosa solą fizjologiczną, z uwagi na możliwość rozprzestrzeniania się wirusów.

Już w marcu 2020 r. grupa Allergic Rhinitis and its Impact on Asthma (ARIA) i Europejskiej Akademii Alergologii i Immunologii Klinicznej (EAACI, European Academy of Allergy and Clinical Immunology) [12] opublikowały zalecenie, aby u chorych z alergicznym nieżytem nosa i COVID-19 nie przerywać stosowania dnGKS: „Zgodnie z obecnym stanem wiedzy, $\mathrm{u}$ pacjentów z zakażeniem wirusem SARS-CoV-2 można kontynuować stosowanie donosowych glikokortykosteroidów (w tym aerozolu) w alergicznym zapaleniu błony śluzowej nosa $\mathrm{w}$ zalecanych dawkach. Nie zaleca się zaprzestania stosowania miejscowych glikokortykosteroidów donosowych. Nie udowodniono działania supresyjnego na układ odpornościowy, a częstsze kichanie po zaprzestaniu stosowania glikokortykosteroidów oznacza większe rozprzestrzenianie się koronawirusa. Zalecenia te mają charakter warun- kowy, ponieważ nie ma wystarczającej ilości danych i powinny być regularnie weryfikowane w miarę zdobywania nowej wiedzy".

Obecnie dysponujemy większą liczbą badań wieloośrodkowych i rekomendacjami międzynarodowych i krajowych towarzystw naukowych i grup ekspertów. Niektóre towarzystwa naukowe wydały zalecenia dotyczące anosmii i zaproponowały przyjmowanie dnGKS. Najczęściej prezentowany i cytowany jest schemat opracowany przez Brytyjskie Towarzystwo Rynologiczne (BRS, British Rhinological Society) [13].

Według zaleceń BRS pierwszy etap terapii zaburzeń węchu powinien być oparty na lekach przeciwzapalnych (dnGKS). Stosując nowoczesne dnGKS, wykorzystujemy prawie pół wieku doświadczeń $\mathrm{w}$ leczeniu alergicznych zapaleń błony śluzowej nosa oraz ostrych i przewlekłych stanów zapalnych błony śluzowej nosa o niealergicznej etiologii, $\mathrm{w}$ tym przewlekłego zapalenia zatok przynosowych z polipami i bez polipów nosa $[14,15]$. Bezpieczeństwo nowoczesnych dnGKS zostało potwierdzone zarówno u dorosłych, jak i u dzieci w wielu badaniach [16]. Regeneracja nabłonka węchowego uszkodzonego w przebiegu infekcji wirusowej zwykle przebiega bardzo sprawnie bezpośrednio po ustąpieniu procesu zapalnego (jeśli nie trwał on długo). W przypadku przedłużających się procesów zapalnych w błonie śluzowej nosa, a szczególnie w regionie pola węchowego, może dojść do długotrwałego uszkodzenia zmysłu węchu. Dlatego ważne jest, aby poprzez zastosowanie terapii przeciwzapalnej dnGKS ograniczyć proces zapalny [10]. Działanie przeciwzapalne prowadzi do zmniejszenia obrzęku błony śluzowej nosa i przywrócenia prawidłowego drenażu jam zatok przynosowych, a także wpływa na regenerację błony śluzowej nosa i przywracanie jej prawidłowej funkcji, szczególnie w zakresie odnowy komórek urzęsionych oraz odbudowy działania całego aparatu śluzowo-rzęskowego, odpowiedzialnego za transport śluzu oraz usuwanie zanieczyszczeń i drobnoustrojów [10].

\section{Trening węchowy}

Z trwałą i/lub długotrwałą utratą węchu spotykaliśmy się już wcześniej $\mathrm{w}$ „dobie przedcovidowej". Olbrzymie znaczenie zmysłu węchu skłaniało zarówno neurologów, jak i rynologów do poszukiwania metod leczniczych przywracających funkcje zmysłu węchu. Duża plastyczność neuronalna narządu węchu stwarza możliwości leczenia za pomocą stymulacji zmysłu węchu poprzez codzienną ekspozycję na określone zapachy [17]. Sorokowska 
Rycina 1. Schemat postępowania w przypadku stwierdzenia utraty węchu w trakcie pandemii COVID-19 wedtug ENT UK [13].

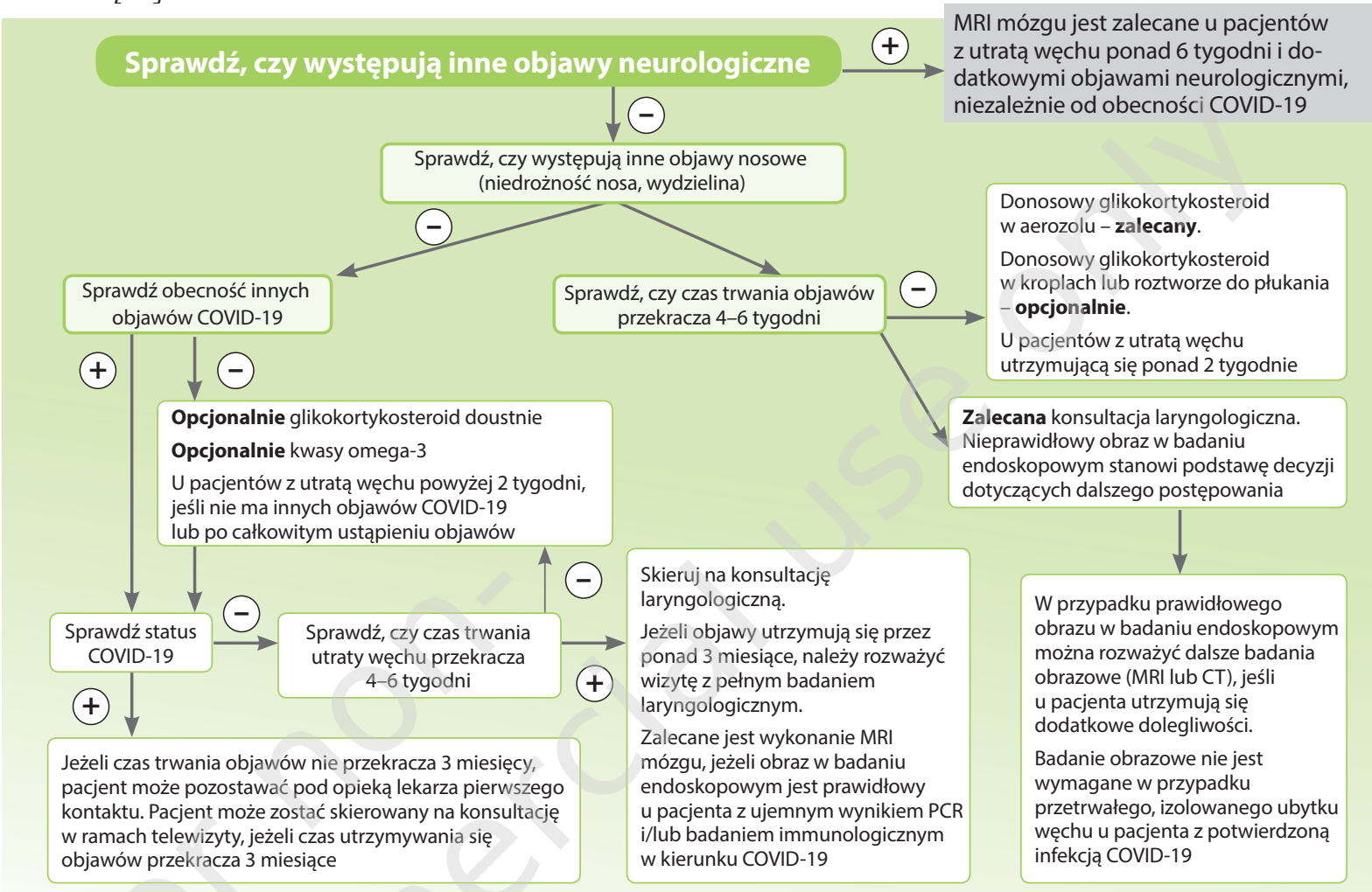

Opcjonalnie oznacza, że konsensus grupy ekspertów Brytyjskiego Towarzystwa Rynologicznego został osiągnięty przy progu na poziomie $60 \%$, a nie 70\%, podkreślając ciągłą niepewność dotyczącą zastosowania.

Obecność COVID-19 powinna być ustalona poprzez wywiad/badanie PCR/badanie immunologiczne u wszystkich pacjentów, jeśli to możliwe. Trening węchowy zalecany jest pacjentom, u których utrata węchu trwa ponad 2 tygodnie.

i wsp. [17] w 2017 r. przeprowadzili metaanalizy efektów treningu węchowego opisanego w 13 publikacjach. Przeanalizowali skuteczność treningu węchu w odniesieniu do identyfikacji zapachów, dyskryminacji i progu wykrywania zapachów. Autorzy [17] stwierdzili znaczący, pozytywny efekt treningu węchowego dla wszystkich trzech ocenianych zdolności węchowych, z największym wpływem treningu na identyfikację, dyskryminację oraz z małym lub umiarkowanym efektem na próg wykrywania zapachu. Wyniki różniły się dla wszystkich testów sniffin sticks w zależności od przyczyny zaburzeń węchu. Długość (czas) prowadzenia treningu węchowego wpływała na jego skuteczność w przypadku identyfikacji. Autorzy [17] podkreślają, że mimo iż dokładny mechanizm poprawy funkcjonowania zmysłu węchu po treningu węchowym wymaga dalszych badań, to przeprowadzona metaanaliza wykazała, że trening powinien być traktowany jako uzupełnienie lub alternatywa dla istniejących metod terapii zaburzeń zmysłu węchu [17]. Damm i wsp. [18] w opublikowanej w 2014 r. pracy wykazali wysoką skuteczność treningu węchowego u chorych z poinfekcyjną utratą węchu. Codzienny trening węchowy z użyciem olejków aromatycznych o wysokim stężeniu u pacjentów z anosmią po infekcjach górnych dróg oddechowych był oceniany w randomizowanym, kontrolowanym, wieloośrodkowym badaniu opublikowanym w 2003 r. przez Gottfrieda i wsp. [19]. Autorzy stwierdzili, że po 18 tygodniach treningu węchowego funkcja zmysłu węchu poprawiła się u 63\% chorych, u których czas trwania dysfunkcji węchu był krótszy niż 12 miesięcy, w porównaniu z 19\% w grupie kontrolnej stosującej olejki o niskim stężeniu. Podobne wyniki uzyskali Konstantinidis i wsp. [20] (publikacja z 2016 r.).

Doświadczenia dotyczące treningu węchowego u osób $\mathrm{z}$ anosmią poinfekcyjną zdobyte w ostatnich kilkunastu latach dziś możemy wykorzystywać $\mathrm{u}$ chorych z anosmią w przebiegu COVID-19. Niespotykana dotychczas skala problemu związanego z anosmią oraz niepełna skuteczność farmakoterapii spowodowały wzrost zainteresowania lekarzy treningiem węchowym. 
Zespół prof. Fabrice’a Denisa (Francja) opracował schemat treningu węchowego stosowany obecnie (lipiec 2021 r.) powszechnie w całej Europie. Wspólnie z grupą terapeutów i organizacją osób cierpiących na zaburzenia węchu stworzyli oni stowarzyszenie (anosmie.org) oraz zaprojektowali aplikację na urządzenia mobilne ułatwiającą i motywującą chorych do regularnych treningów węchowych (covidanosmie.fr) [21]. Aplikacja covidanosmie.fr została zaprojektowana $\mathrm{w}$ celu zapewnienia spersonalizowanych porad i monitorowania pacjentów z częściową lub całkowitą utratą węchu w przebiegu COVID-19 poddawanych rehabilitacji węchowej (trening węchowy).

Program rehabilitacji węchowej polega na połączeniu stosowania 2 razy dziennie wysoko skoncentrowanych olejków aromatycznych oraz modułu stymulacji wizualnej. Aplikacja codziennie podpowiada choremu, w jakiej kolejności powinien stosować te olejki, jak powinien postępować, a kilka razy w tygodniu zachęca go do wypełnienia kwestionariusza umożliwiającego pomiar i indywidualne monitorowanie postępów. Cztery substancje zapachowe zostały zaproponowane w 2019 r. przez zespół prof. Thomasa Hummela [22].

\section{Schemat treningu węchowego według anosmie.org [21]}

Trening węchowy - zalecany u pacjentów z utratą węchu dłuższą niż 2 tygodnie.

Trening węchowy - zalecany u wszystkich chorych z utratą węchu, niezależnie od etiologii.

Trening węchowy - powinien być prowadzony regularnie, długotrwale, do powrotu prawidłowej funkcji zmysłu węchu, co najmniej przez 12 tygodni.

Trening węchowy - cztery grupy zapachów, prezentowane co najmniej 2 razy dziennie:

- róża (alkohol fenyloetylowy)

- eukaliptus (eukaliptol)

- cytryna (cytronelal)

- goździk (eugenol).

W pierwszej kolejności należy wąchać każdy z zapachów przez co najmniej 15 s z zamkniętymi oczami (lub z ukrytym opisem substancji zapachowej), a następnie przez 15-30 s powinno się wąchać substancję, widząc jednocześnie jej nazwę (skład). Trening powinien być prowadzony 2 razy dziennie, rano i wieczorem, co daje w sumie cztery ekspozycje dziennie na jeden zapach. Codziennie pacjent powinien zapisywać efekt treningu węchowego w tabeli $\mathrm{w}$ wizualnej skali analogowej od 1 do 10 . Zwiększa to szansę na systematyczne treningi oraz pozwala na ocenę wyników rehabilitacji zmysłu węchu.

W swojej praktyce, z uwagi na utrudniony dostęp do profesjonalnych zestawów substancji używanych do terapii węchowej, stosuję u pacjentów łatwo dostępne naturalne produkty spożywcze oraz olejki wykorzystywane w przemyśle spożywczym (dostępne w sklepach spożywczych - zapachy do ciasta) lub aromaty używane do tytoniu. Produkty te są łatwo dostępne. Wstępne wyniki moich obserwacji wskazują na korzyści płynące z połączenia farmakoterapii dnGKS z treningiem węchowym. Jest jednak zbyt wcześnie, abym mógł się z Państwem podzielić wynikami leczenia. Brakuje standaryzacji aromatów, każdy z moich chorych stosuje różne zestawy aromatów, okres obserwacji jest stosunkowo krótki, a grupa pacjentów poddana rehabilitacji węchowej nieliczna i niejednorodna, jeśli chodzi o przyczynę anosmii. Na podstawie analizy literatury i swoich dotychczasowych obserwacji jestem jednak przekonany o konieczności zalecania chorym $\mathrm{z}$ anosmią poinfekcyjną treningu węchowego.

Mój autorski zestaw zapachów do treningu węchowego:

1. Cytryna (owoc) lub aromat cytrynowy

2. Aromat spożywczy waniliowy

3. Aromat spożywczy - mięta

4. Aromat-goździki

5. Świeżo zmielona kawa

6. Owoce i warzywa sezonowe.

\section{Podsumowanie}

Zmysł węchu jest jednym z najbardziej niedocenianych zmysłów. Dopiero jego trwała dysfunkcja uświadamia chorym, jak wielkie jest jego znaczenie. $\mathrm{W}$ ostatnich latach, z uwagi na częste występowanie powirusowego uszkodzenia zmysłu węchu w przebiegu COVID-19 znacząco wzrosło zainteresowanie zarówno lekarzy, jak i pacjentów rehabilitacją zmysłu węchu. Trening węchowy jest szczególnie skuteczny $\mathrm{u}$ chorych z utratą węchu po infekcjach górnych dróg oddechowych, nie tylko u osób po COVID-19, lecz także przy zaburzeniach węchu powstałych w przebiegu innych chorób infekcyjnych. Duża łatwość prowadzenia treningu węchowego, jego niski koszt i brak ograniczeń technicznych oraz angażująca chorego forma treningu stanowi o atrakcyjności i użyteczności tej metody terapii.

Trening węchowy wymaga jednak ze strony pacjenta dużej samodyscypliny. Warto zachęcić chorych 
do tej formy leczenia, pamiętając jednak o równoległym, regularnym stosowania farmakoterapii (nowoczesne dnGKS).

\section{Piśmiennictwo}

1. Boscolo-Rizzo P, Borsetto D, Fabbris C et al. Evolution of altered sense of smell or taste in patients with mildly symptomatic COVID-19. JAMA Otolaryngol Head Neck Surg. 2020; 146(8): 729-32. http://doi.org/10.1001/jamaoto.2020.1379.

2. Le Bon S-D, Pisarski N, Verbeke J et al. Psychophysical evaluation of chemosensory functions 5 weeks after olfactory loss due to COVID-19: a prospective cohort study on 72 patients. Eur Arch Otorhinolaryngol. 2020; 278: 101-8. http://doi. org/10.1007/s00405-020-06267-2.

3. Vaira LA, Hopkins $C$, Petrocelli $M$ et al. Smell and taste recovery in coronavirus disease 2019 patients: a 60-day objective and prospective study. J Laryngol Otol. 2020; 134: 703-9. http://doi.org/10.1017/S0022215120001826.

4. Hura N, Xie DX, Choby GW et al. Treatment of post-viral olfactory dysfunction: an evidence-based review with recommendations. Int Forum Allergy Rhinol. 2020; 10: 1065-86. http://doi.org/10.1002/alr.22624.

5. Heilmann S, Huettenbrink K-B, Hummel T. Local and systemic administration of corticosteroids in the treatment of olfactory loss. Am J Rhinol. 2004; 18: 29-33. http://doi. org/10.1177/194589240401800107.

6. Miwa T, Ikeda K, Ishibashi T et al. Clinical practice guidelines for the management of olfactory dysfunction: secondary publication. Auris Nasus Larynx. 2019; 46: 653-62. http:// doi.org/10.1016/j.anl.2019.04.002.

7. Whitcroft KL, Hummel T. Olfactory dysfunction in COVID-19. JAMA. 2020, 323: 2512. http://doi.org/10.1001/ jama.2020.8391.

8. Rapiejko P. Zaburzenia zmyshu węchu. Medical Education, Warszawa 2016.

9. Rapiejko P. Badanie zmystu węchu. In: Niemczyk K, Jurkiewicz D, Składzień J et al (ed). Otolaryngologia kliniczna. Vol 1. Medipage, Warszawa 2014: 121-3.

10. Rapiejko P. Zaburzenia zmystu węchu w praktyce lekarza rodzinnego. Alergoprofil. 2021; 17(1): 3-10.

11. Hawkes CH. Smell, taste and COVID-19: testing is essential. QJM. 2021; 114(2): 83-91. http://doi.org/10.1093/qjmed/ hcaa326.

12. Bousquet PJ, Akdis C, Jutel $M$ et al. Intranasal corticosteroids in allergic rhinitis in COVID-19 infected patients: An ARIA-EAACI statement. Allergy. 2020. http://doi.org/10.1111/ all.14302.

13. Hopkins C, Alanin M, Philpott $C$ et al. Management of new onset loss of sense of smell during the COVID-19 pandemic
- BRS Consensus Guidelines. Clin Otolaryngol. 2021; 46: 16-22. http://doi.org/10.1111/coa.13636.

14. Samoliński B, Nowicka A, Wojas $O$ et al. Intranasal glucocorticosteroids - not only in allergic rhinitis In the 40th anniversary of intranasal glucocorticosteroids' introduction. Otolaryngol Pol. 2014; 68(2): 51-64. http://doi.org/10.1016/j. otpol.2013.12.003.

15. Rot P, Rapiejko P, Jurkiewicz D. Intranasal steroid therapyEPOS 2020. Otolaryngol Pol. 2020; 74(3): 41-9. http://doi. org/10.5604/01.3001.0014.2449

16. Nowicka A, Samolinski B. Is the use of intranasal glucocorticosteroids (in GCSs) in children safe? Otolaryngol Pol. 2015; 69(1): 1-10. http://doi.org/10.5604/00306657.1136130.

17. Sorokowska A, Drechsler E, Karwowski M et al. Effects of olfactorytraining: a meta-analysis. Rhinology. 2017; 55: 17-26.

18. Damm M, Pikart LK, Reimann $H$ et al. Olfactory training is helpful in postinfectious olfactory loss: a randomized, controlled, multicenter study. Laryngoscope. 2014; 124(4): 826-31.

19. Gottfried JA, Dolan RJ. The nose smells what the eye sees: crossmodal visual facilitation of human olfactory perception. Neuron. 2003; 39(2): 375-86.

20. Konstantinidis I, Tsakiropoulou E, Constantinidis J. Long term effects of olfactory training in patients with post-infectious olfactory loss. Rhinology. 2016; 54(2): 170-5.

21. Anosmie.org (acesss: 18.07.2021).

22. Hummel T, Iannilli E, Frasnelli $J$ et al. Central processing of trigeminal activation in humans. Ann $N Y$ Acad Sci. 2009; 1170: 190-5. http://doi.org/10.1111/ j.1749-6632.2009.03910.x.

ORCID

P. Rapiejko - ID - http://orcid.org/0000-0003-3868-0294

Konflikt interesów/Conflict of interests:

Nie wysteppuje.

Finansowanie/Financial support:

Nie występuje.

Etyka/Ethics: Treści przedstawione w artykule są zgodne zzasadami Deklaracji Helsińskiej, dyrektywami EU oraz ujednoliconymi wymaganiami dla czasopism biomedycznych.

Copyright: (๑) Medical Education sp. z 0.0. This is an Open Access article distributed under the terms of the Attribution-NonCommercial 4.0 International (CC BY-NC 4.0). License (https://creativecommons.org/licenses/by-nc/4.0/), allowing third parties to copy and redistribute the material in any medium or format and to remix, transform, and build upon the material, provided the original work is properly cited and states its license.

Adres do korespondencji

dr n. med. Piotr Rapiejko

Klinika Otolaryngologii i Onkologii Laryngologicznej

z Klinicznym Oddziałem Chirurgii

Czaszkowo-Szczękowo-Twarzowej, Wojskowy Instytut Medyczny

04-141 Warszawa, ul. Szaserów 128

www.rapiejko.pl 